\title{
Going against the Grain of Ethnic Voting: The Scramble for Votes in the 2013 Presidential Election in Western Kenya
}

\author{
Adams 0100 \\ Department of Political Science and Public Administration, University of Nairobi, \\ Nairobi, Kenya \\ Email: adams_oloo@yahoo.com, aoloo@uonbi.ac.ke
}

Received 3 April 2016; accepted 17 April 2016; published 20 April 2016

Copyright (C) 2016 by author and OALib.

This work is licensed under the Creative Commons Attribution International License (CC BY). http://creativecommons.org/licenses/by/4.0/

(c) (i) Open Access

\begin{abstract}
Political mobilization and voting patterns in Kenya have revolved around ethnicity since the return to multi-party politics in 1992. Since then the contest in successive years has been largely confined to the five big tribes who together constitute around $70 \%$ of the population. These are the Kikuyu, Luhya, Kalenjin, Luo and Kamba in that order. But while the Kikuyu, Kalenjin, Luo and Kamba have in one election or another rallied overwhelmingly behind their kin, the Luhya have been averse to this trend. This was more so in the 2013 election when conventional wisdom dictated that the Luhya's true to Kenyan tradition would rally behind the candidature of Musalia Mudavadi. The results however proved otherwise. This article teases out the factors that have influenced the Luhya's voting pattern generally in addition to specifically assessing the factors that explain Mudavadi's inability to galvanize the Luhya vote akin to candidates from the other four big tribes.
\end{abstract}

Keywords

Ethnicity, Elections, Politics, Running Mate

Subject Areas: Politics

\section{Introduction}

Kenya's political system since the return to multipartyism in 1992 has largely been characterised by ethnic voting. In the 1992, 1997, 2002, 2007 and 2013 elections, ethnicity remained the dominant identity around which political parties were not only formed, but also through which they sought membership and mobilised supporters [1]. Despite this trend, the Luhya—-the second most populous ethnic group in the country—have been averse to 
this mode of voting with a modicum of exception in the 2002 General Election.

The Census' done in 1989, 1999 and 2009 indicate that the Luhya constitute about 13.8 per cent of the Kenyan population, being second only to the Kikuyu who constitute about 17.2 per cent of the population (see Table 1). However, until 2013, the Luhya had not mounted a serious bid for the presidency compared to the other large communities, namely, the Kikuyu, the Kalenjin, the Luo and the Kamba. In spite of this strong bid in the person of Musalia Mudavadi, the Luhyas gave his candidature a wide berth voting overwhelmingly instead for his rival Raila Odinga from the Luo community.

During the 1992 General Election, the Luhya did not field any presidential candidate thus the dispersal of the communities vote amongst three of the four main presidential contenders was understandable. The distribution of the Western province Luhya vote in that election year saw, Daniel arap Moi of KANU garner 40.9 per cent, Kenneth Matiba of FORD-A 36.3 per cent, and Jaramogi Odinga of FORD-Kt 17.9 per cent.

But in subsequent electoral years, the Luhya had their own candidates, namely, Kijana Wamalwa in 1997 and Musalia Mudavadi in 2013. But in both instances, the candidates failed to galvanize their community in contrast to candidates from the other big four communities.

The aim of this paper is to tease out why the Luhya community has consistently gone against the grain of ethnic voting in a country in which big tribes always vote for one of their "own". Among the top five ethnic groups, this is the only tribe that has substantially voted for a candidate other than one of their own even in instances where a member of their ethnic group with a national name is in the race. This has happened in spite of Luhya leaders pleading for Luhya unity. A number of factors combine to explain the trend of non-ethnic block voting among the Luhya. The first factor is sub-tribe rivalry. This rivalry has prevented the sub-tribes from uniting behind a single leader in the region; the second factor is the perennial lack of a single dominant party amongst the Luhya. There is no single political party among the Luhya that has been able to attract the support of all Luhyas; the third factor is the lack of a common heritage. The sub-tribes do not share a lot in common in terms of their heritage or even language which has worked as a factor amplifying differences rather than illuminating commonality and unity; the fourth factor is the weak financial muscle of successive Luhya presidential candidates. This has constrained the leaders to be able to campaign across the region as well as nationally so as to convince the locals that they have the wherewithal to fight it out with leaders from other regions; and, the fifth factor is the lack of a dominant charismatic character with pedigree to bring the community together. Most of the leaders from the region have been unable to attract the requisite respect to convince the rest of the sub-tribes to rally behind one of them.

\section{The 1992 General Election: The Genesis of Luhya Disunity in Electoral Politics}

Between 1963 and 1988 Kenyans never went to the ballot to vote for a presidential candidate. In 1963, the country went to elections under a pure parliamentary system while in the subsequent election years, that is, 1969, 1974, 1979, 1983 and 1988, Kenya was either a de facto or a de jure one-party state and the nominee of the ruling party automatically became President since the constitution did not provide for independent candidates.

The year 1992 was therefore the first time that Kenyans were offered a chance from which to choose a presidential candidate after the repeal of Section 2 (a) of the Constitution which had made Kenya a de jure one-party state in 1992. The presidency was contested by four main contenders, namely, Daniel arap Moi, Kenneth Matiba, Mwai Kibaki and Jaramogi Odinga who represented three of the five big tribes, i.e., the Kikuyu, the Kalenjin

Table 1. Population share (\%) of the big five.

\begin{tabular}{cccccc}
\hline Census Year & Kikuyu & Luhya & Kalenjin & Luo & Kamba \\
\hline 1962 & 18.8 & 12.7 & 10.8 & 13.4 & 10.5 \\
1969 & 20.1 & 13.3 & 10.9 & 13.9 & 10.9 \\
1979 & 20.9 & 13.8 & 10.8 & 13.2 & 11.3 \\
1989 & 20.8 & 14.4 & 11.5 & 12.4 & 11.4 \\
2003 (DHS) & 22.9 & 14.9 & 10.6 & 12.0 & 11.5 \\
2009 & 17.2 & 13.8 & 12.9 & 10.8 & 10.1 \\
\hline
\end{tabular}

Note: Except for 2003, we use the Kenya Population and Housing Census to estimate the shares of each ethnic group. The ethnic data for the 1999 census was never made public, and we use the nationally representative Kenya Demographic and Health Survey 2003 instead. 
and the Luo. Although the Kamba — the other big tribe — had a candidate in the name of Harun Mwau of Party of Independent Candidates of Kenya (PICK) he was a fringe candidate who was not nationally recognized. To paraphrase Horowitz, the 1992 General Election was an "ethnic census" of the loyalty of the majority big tribes who had presidential candidates [2]. The Luhya were the only big community without a candidate in the 1992 General Election.

In conformity with what would later turn to be a pattern of ethic block voting, as Table 2 shows, the Kalenjins rallied behind one of their own, incumbent President Moi, the Luo rallied behind their kinsman, Jaramogi Odinga while the Kikuyu divided their votes between two of their prominent sons, Kenneth Matiba and Mwai Kibaki. The other two big tribes, namely, the Kamba and the Luhya split their votes. The Kamba split their votes between Moi and Kibaki, while the Luhya split their votes threefold between Moi, Matiba and Odinga with their prominent sons, Musalia Mudavadi, Martin Shikuku and Kijana Wamalwa delivering the votes for each of their presidential candidates respectively [3].

Each of these Luhya kingpins had a strategic position in their respective parties. Musalia Mudavadi was a serving Cabinet minister in the Moi government and as a political ruse, Moi dangled the possibility of him ascending to the Vice-Presidency-a position which was ostensibly dangled to other regional kingpins as well. Shikuku was the Secretary-General of the FORD-A, and therefore, the second in command in the party. In fact, he contested the FORD-A primaries, which he lost to Matiba before throwing his lot with him. Wamalwa was the second Vice-Chairman of the FORD-K, and also rode on the legacy of the late Masinde Muliro who was deemed to be leaning towards the Odinga faction of the Forum for the Restoration of Democracy (FORD), at the time of his death [4].

The split in the Luhya vote, though not unique in this election, was significant in the sense that the Luhya did not have a formidable candidate, and therefore, were not splitting votes among their own like the Kikuyu did between Kibaki and Matiba, but were splitting them amongst candidates from other tribes.

\section{The 1997 General Election: Sub-Tribe Rivalry Jolts the Quest for Luhya Unity}

The 1997 General Election provided the Luhya with the first opportunity after the return to multiparty politics to flex their political muscle in the ethnic dominated political arena that has characterised Kenyan politics since 1992. During that year's election, the Luhya had a party that they could call their own thanks to the rivalry between Raila Odinga and Kijana Wamalwa over the control of FORD-K after the death of Jaramogi Odinga. The heated rivalry saw Raila Odinga decamping from FORD-K to revive the then moribund National Development Party (NDP), thus leaving Wamalwa Kijana in control of FORD-K as its chairman and presidential candidate in the 1997 General Election. Also in the race was Martin Shikuku of FORD-A, who was now in control of the party having split with Kenneth Matiba, who had founded Saba Saba Asili even though he did not offer himself for the presidency in the 1997 General Election.

Table 2. 1992 Presidential election results by province.

\begin{tabular}{ccccccccc}
\hline Region & Moi & $\mathbf{\%}$ & Matiba & $\mathbf{\%}$ & Kibaki & \% & Odinga & \% \\
Nairobi & 62,402 & 16.6 & $\mathbf{1 6 5 , 5 3 3}$ & $\mathbf{4 4 . 1}$ & 69,715 & 18.6 & 75,898 & 20.2 \\
Central & 21,882 & 2.1 & $\mathbf{6 2 1 , 3 6 8}$ & $\mathbf{6 0 . 1}$ & 372,937 & 36.1 & 10,765 & 1.0 \\
Eastern & 290,494 & 36.8 & 80,515 & 10.2 & $\mathbf{3 9 8 , 7 2 7}$ & $\mathbf{5 0 . 5}$ & 13,064 & 1.7 \\
North Eastern & $\mathbf{5 7 , 4 0 0}$ & $\mathbf{7 8 . 1}$ & 7460 & 10.1 & 3297 & 4.5 & 5237 & 7.1 \\
Coast & $\mathbf{2 0 0 , 5 9 6}$ & $\mathbf{6 4 . 1}$ & 35,598 & 11.4 & 23,766 & 7.6 & 50,516 & 16.1 \\
Rift Valley & $\mathbf{9 9 4 , 8 4 4}$ & $\mathbf{6 7 . 8}$ & 274,011 & 18.7 & 111,098 & 7.6 & 83,945 & 5.7 \\
Western & $\mathbf{2 1 7 , 3 7 5}$ & $\mathbf{4 0 . 9}$ & 192,859 & 36.3 & 19,115 & 3.6 & 94,851 & 17.9 \\
Nyanza & 111,873 & 14.4 & 26,922 & 3.3 & 51,962 & 6.4 & $\mathbf{6 0 9 , 9 2 1}$ & $\mathbf{7 4 . 7}$ \\
Total & $\mathbf{1 , 9 5 6 , 8 6 6}$ & 36.4 & $1,404,266$ & 26 & $1,050,617$ & 19.5 & 944,197 & 17.5 \\
\hline
\end{tabular}

Source: Constructed from defunct Electoral Commission of Kenya, ECK, results. 
But in spite of fielding two presidential candidates with national stature, the Luhya's failed to overwhelmingly rally behind one of their two "sons". For Martin Shikuku, his clout amongst a section of the Luhya community as demonstrated in the 1992 General Election had waned. This can be explained by a number of factors. First, the national status of FORD-A waned after the departure of Kenneth Matiba and before that several MPs elected from Luhyaland (Nicodemus Khaniri, Ajuli Wawire, Jovan Onnani, Benjamin Magwaga and Japheth Shamalla) on FORD-A ticket to the 7th Parliament had defected back to KANU [5]. Thus, by 1997, he was leading a party that was on a downward spiral. Second, Martin Shikuku lacked the financial muscle necessary for a presidential race. His candidature was thus seen as a smokescreen to get himself elected as an MP for Butere Constituency, which he also lost.

Against this background, the main hope for the Luhya community for a formidable shot for the presidency was Wamalwa Kijana. The party he led-FORD-K—although hit by defections between 1992 and 1997, still had a national outlook, and in addition, it could now lay claim to be the party of the Luhyas with Wamalwa at the helm. However, Wamalwa's performance nationally and within his community was wanting. Although he scored the highest percentage of votes in the Luhya dominated Western Kenya garnering 48.2 per cent of the vote against Moi's 44.9 per cent in the same region, the performance was perceived as dismal compared to how presidential candidates from the other big four tribes had performed in their respective backyards. Moi as expected got strong Kalenjin backing securing 69.5 per cent of the votes in the Kalenjin dominated but cosmopolitan Rift Valley. Kibaki, in the absence of Matiba, scored 89.4 per cent of the votes in the Kikuyu dominated Central Kenya. Raila Odinga, under NDP, garnered 56.8 per in the Luo dominated Nyanza province that has a sizeable Kisii population in addition to the Kuria while Charity Ngilu secured 33.6 per cent in Eastern province mostly from her Kambaland backyard (see Table 3). It is instructive to note that the Kalenjin, the Kikuyu and the Luo put their votes in one basket behind their "sons" while the Luhya divided their vote between Wamalwa's FORD-K and Moi's KANU while the Kamba divided their votes between Ngilu's Social Democratic Party (SDP) and Moi's KANU.

A number of factors may explain the Luhya's disunity in the 1997 General Election. First was sub-tribe rivalry. Wamalwa Kijana as already mentioned was a Bukusu. His main support from the Luhya was therefore largely drawn from this sub-tribe, as is also evident from the fact that his party swept all the Luhya parliamentary seats in the Bukusu-dominated strongholds of Bungoma and Trans-Nzoia districts. This however was not the case in the districts of Kakamega, Vihiga and Busia that are dominated by other non-Bukusu sub-tribes of the Luhya. Second, Wamalwa Kijana and his party FORD-K lacked financial muscle to the extent that most of his campaigns were held in his Western Kenya backyard. This, combined with the fact that KANU, had a well oiled campaign machinery, together with a point person in the form of Musalia Mudavadi, denied Wamalwa inroads into Kakamega, Vihiga and Busia similar to the one he had in Bukusuland. Third, FORD-K as a party was not yet embraced across Luhyaland the way KANU was embraced in Kalenjinland and NDP in Luoland in the same electoral year.

Table 3. 1997 Presidential election result by province.

\begin{tabular}{ccccccccccc}
\hline Region & Moi & \% & Kibaki & \% & Raila & \% & Wamalwa & \% & Ngilu & \% \\
\hline Central & 56,367 & 5.6 & $\mathbf{8 9 1 , 4 8 4}$ & $\mathbf{8 9 . 4}$ & 6869 & 0.7 & 3058 & 0.3 & 30,535 & 3.1 \\
Rift Valley & $\mathbf{1 , 1 4 0 , 1 0 9}$ & $\mathbf{6 9 . 5}$ & 343,529 & 21 & 36,022 & 2.2 & 102,178 & 6.2 & 11,345 & 0.7 \\
Western & 314,669 & 44.9 & 9755 & 1.4 & 13,458 & 1.9 & $\mathbf{3 3 8 , 1 2 0}$ & $\mathbf{4 8 . 2}$ & 3429 & 0.5 \\
Nyanza & 215,923 & 23.6 & 138,202 & 15.1 & $\mathbf{5 1 9 , 1 8 0}$ & $\mathbf{5 6 . 8}$ & 14,623 & 1.6 & 15,301 & 1.7 \\
Eastern & $\mathbf{3 7 0 , 9 5 4}$ & $\mathbf{3 5 . 6}$ & 296,335 & 28.5 & 7787 & 0.7 & 7017 & 0.7 & 349,754 & 33.6 \\
Nairobi & $\mathbf{7 5 , 2 7 2}$ & 20.6 & $\mathbf{1 6 0 , 1 2 4}$ & $\mathbf{4 3 . 9}$ & 59,415 & 16.3 & 24,971 & 6.8 & 39,707 & 10.9 \\
Coast & $\mathbf{2 5 7 , 0 5 6}$ & $\mathbf{6 3 . 4}$ & 51,909 & 12.8 & 24,844 & 6.1 & 11,306 & 2.8 & 38,089 & 9.4 \\
North Eastern & $\mathbf{7 0 , 5 0 6}$ & $\mathbf{7 3 . 2}$ & 20,404 & 21.2 & 311 & 0.3 & 4431 & 4.6 & 440 & 0.5 \\
Total & $\mathbf{2 , 5 0 0 , 8 5 6}$ & $\mathbf{4 0 . 6}$ & $1,911,742$ & 31 & 667,886 & 10.8 & 505,704 & 8.2 & 488,600 & 7.9 \\
\hline
\end{tabular}

Source: Constructed from defunct Electoral Commission of Kenya, ECK, results 


\section{The 2002 General Election: Luhya Unity or National Grievance}

Since the return to multiparty politics in 1992, it is the 2002 General Election that saw some modicum of Luhya unity in the presidential vote. Yet significantly, there was no Luhya candidate of national stature on the presidential ballot paper. Instead, Luhyas were unofficially positioned as running mates for the leading contenders. In NARC, Mwai Kibaki had Kijana Wamalwa as Vice President designate while KANU’s Uhuru Kenyatta whose potential designate was Vice-President Musalia Mudavadi. It is instructive to note that Mudavadi had bolted out of the Rainbow Alliance-a renegade KANU group that went ahead to form the Liberal Democratic Party $(\mathrm{LDP})^{1}$ and later entered into a coalition with the NAK ${ }^{2}$ that gave birth to NARC. It is also instructive to note that the LDP, before it joined with the Nationa Alliance Party of Kenya (NAK) that had Kibaki's DP, Wamalwa's FORD-K and Ngilu's SDP, had a number of Luhya luminaries within its fold. These included Moody Awori, who would later become the Vice-President after Wamalwa's death, Fred Gumo, Andrew Ligale, Wycliffe Osundwa among others [6] [7].

The formation of the NARC, however, erased the fault-lines in Luhyaland between the LDP and FORD-K and with Mudavadi back in KANU, FORD-K's Wamalwa became the undisputable face of the Luhya in the NARC. This was further solidified under the Memorandum of Understanding (MoU) that designated him as the Vice-President in the event of a NARC win. NARC as already alluded to earlier not only brought several parties to a coalition, it also brought blocks of ethnic groups that had been fatigued by the Moi's regime continued hold on power and dictatorial tendencies. It was against this background that several communities that had hitherto supported the KANU rejected Moi's unilateral decision to designate Uhuru Kenyatta as his successor. The result was the renegade rainbow rebellion led by Raila Odinga whose NDP had in the run-up to the 2002 General Election merged with KANU. Previous hawkish KANU politicians led their communities out of KANU including Mudavadi-the Luhya, Kalonzo — the Kamba, Ntimama - the Maasai among others. And when Mudavadi gave in to the KANU regime pressure, Awori, though not a national figure then, was fronted to fill the vacuum left by Mudavadi in the renegade Rainbow ranks.

The ethnicised nature of Kenyan politics meant that when the NARC crafted the MoU, it was not only about parties bargaining for positions but ethnic kingpins being promised a piece of the pie as a bait to galvanise their communities behind the NARC presidential candidate. Under the MoU, therefore, Kibaki, a Kikuyu, was to be the presidential candidate, Wamalwa, a Luhya, was to be the Vice-President and Raila, a Luo, was to be the Prime Minister. Due to the fact that there were no enough top positions to go around, horse trading led to positions that had not been envisaged under the Bomas Draft Constitution being bandied around like the position of 2nd Vice-President which Kalonzo Musyoka was promised. Under this framework, Wamalwa Kijana became the face of the Luhya in the NARC coalition (see Table 4).

Table 4. 2002 Presidential election results by province.

\begin{tabular}{|c|c|c|c|c|c|c|c|c|c|c|}
\hline Region & Kibaki & $\%$ & Kenyatta & $\%$ & Nyachae & $\%$ & Orengo & $\%$ & Ng'ethe & $\%$ \\
\hline Central & 701,916 & 68.9 & 308,012 & 30.2 & 4441 & 0.4 & 1443 & 0.1 & 2053 & 0.2 \\
\hline Coast & 228,915 & 62.7 & 121,645 & 33.4 & 11,716 & 3.2 & 1539 & 0.4 & 823 & 0.2 \\
\hline Eastern & 749,654 & 72.5 & 270,225 & 26.1 & 7863 & 0.8 & 3509 & 0.3 & 2216 & 0.2 \\
\hline Nairobi & 279,705 & 76.4 & 76,001 & 20.8 & 8775 & 2.4 & 891 & 0.2 & 301 & 0.1 \\
\hline North Eastern & 34,916 & 28.1 & 83,358 & 67.1 & 5660 & 4.6 & 297 & 0.2 & 73 & 0.1 \\
\hline Nyanza & 521,052 & 61.3 & 64,471 & 7.6 & 252,448 & 29.7 & 9620 & 1.1 & 1115 & 0.1 \\
\hline Rift Valley & 624,501 & 43.2 & 769,242 & 53.3 & 45,145 & 3.1 & 3826 & 0.3 & 1624 & 0.1 \\
\hline Western & 506,999 & 76.3 & 143,101 & 21.5 & 9073 & 1.4 & 3443 & 0.5 & 1825 & 0.3 \\
\hline Total & $3,647,658$ & 61.3 & $1,836,055$ & 30.2 & 345,161 & 5.9 & 24,568 & 0.4 & 10,030 & 0.1 \\
\hline
\end{tabular}

Source: Constructed from defunct Electoral Commission of Kenya, ECK, results.

\footnotetext{
${ }^{1}$ The NAK was made up of about 13 different political opposition parties with the DP, the SDP and the FORD-K being the key constituent parties.

${ }^{2}$ The LDP was made up of KANU MPs including some ministers who abandoned the party to from the Rainbow Alliance. These included the former Vice-President George Saitoti, the MP for Kajiado North in the Rift Valley; the long-serving Secretary General of the KANU, Joseph Kamotho from Kangema in Central Province; Kalonzo Musyoka, a long-serving cabinet minister and immediate former KANU vice president for Eastern Province; William ole Ntimama, a former long-serving cabinet minister from Maasailand and at one time a close ally of Moi; Joseph Nyaga, a former cabinet minister from Embu in Eastern Province; Moody Awori and Fred Gumo, both former assistant ministers in the KANU government, both of whom hail from Busia district in Western Province.
} 
It is with the foregoing that it becomes less certain to infer whether the massive Luhya vote for Kibaki was delivered under the tutelage of Wamalwa or whether the coalescing of the Luhya votes behind Kibaki was a combination of Wamalwa and renegade Luhya luminaries that were domiciled in the LDP. This is critical because there are various communities in Kenya that have rallied behind a party or presidential candidate without having a designated kingpin but instead diverse point men. These include the coastal tribes in successive elections and the Kamba backing for Moi in the 1992 and 1997 General Election. The fact that Wamalwa died so soon after the NARC victory and was replaced by a Luhya, Awori from the LDP wing of the coalition, further makes the analysis dicey. It is however not in question that the Luhya voted in block because of Wamalwa's designated position as Vice-President to be since they were assured of a stake in the NARC government. But the same could also be said that the NARC coalition presented a moment in Kenyan politics that ethnic grievances and identity got conflated into a national course that for the immediate period promised to slay the trend of electoral politics being an "ethnic census". The Luo who had since independence perceived the Kikuyu to have betrayed their course voted for Kibaki almost to a man in spite of James Orengo—a fiery Luo politician—being on the presidential ballot. The Maasai who had stuck with Moi since the Kenya African Democratic Union (KADU) days broke ranks. The Kamba, who had never voted as a block before, rallied behind Kibaki, and the coastal tribes which had hitherto supported Moiand KANU also followed suit. Luhyaland too was also not spared of this wave. The NARC wave swept the whole country with the exception of Moi's Kalenjinland. It is in this vein that I argue that the only election in which the Luhya voted with some modicum as a block was influenced more by the national character of the coalition and accumulated grievances against the Moi regime rather than raw ethnic nationalism that has characterised other multiparty elections.

\section{The 2007 General Election: A Demonstration of the Elusive Luhya Unity}

The 2007 General Election was the climax of a political process that had its roots in the referendum of 2005. The 2005 referendum served as the final breaking point of the fragile NAK and LDP convalescence. In the 2005 referendum, Luhyaland became a battlefield as FORD-K threw its weight behind the "Yes" team led by President Kibaki while LDP threw its weight behind the "No" vote led by the Minister for Roads and Public Works, Raila Odinga. The five big tribes with the exception of the Luhya voted as a block with the Kikuyu (93.2 per cent) voting "Yes" in conformity with President Kibaki's position while the Luo (87.8 per cent), Kalenjin (87.8 per cent) and Kamba overwhelmingly voting for the "No" camp. While 59.8 per cent of Western dominated Luhyaland voted "no" an equally impressive 40.2 per cent voted "Yes" (see Table 5).

This scenario was replicated in the 2007 presidential elections. Once more, there was no Luhya presidential candidate but just or even more than the 2002 General Election all the running mates and sitting Vice-President for the key presidential candidates came from the Luhya community. The incumbent Mwai Kibaki's VicePresident, Moody Aworu, was a Luhya. Raila Odinga, the ODM presidential candidate, proclaimed Musalia Mudavadi as his running mate and the ODM-K candidate, Kalonzo Musyoka, after some haggling, also proclaimed Julia Ojiambo, a Luhya, as his running mate.

Table 5. 2005 referendum results by province.

\begin{tabular}{cccc}
\hline Province & Yes & No \\
\hline Nairobi & 43.2 & 56.8 \\
Coast & 19.3 & 80.7 \\
North Eastern & 24.1 & 75.9 \\
Eastern & 49.5 & 50.5 \\
Central & 93.2 & 6.8 \\
Rift Valley & 24.5 & 75.5 \\
Western & 40.2 & 59.8 \\
Nyanza & 12.2 & 87.8 \\
Total & 41.7 & 58.3 \\
\hline
\end{tabular}

Source: Constructed from defunct Electoral Commission of Kenya, ECK, results. 
Just like in the previous elections, there was no dominant party in Luhyaland as compared to the other big four tribes. The Kikuyus were enmeshed in the PNU coalition, the Luos were untied in the ODM, while the Kalenjin had also moved enmass to the ODM with only an insignificant segment of the community remaining in the KANU. The Luhya true to their diverse character were spread in unequal proportions in three main parties. These were the ODM, the FORD-K and the splinter New Ford Kenya. As the 2007 results demonstrated, a majority of the Luhya were allied to the ODM compared to the FORD-K and the NFK. It is also instructive to note that unlike the FORD-K and NFK which were under the leadership of Luhyas, the ODM was under the leadership of a Luo with a Luhya deputizing. But in spite of this, Raila Odinga of the ODM garnered 65.9 per cent of the Western Province Luhya vote while FORD-K and NFK shared the remaining (see Table 6). During the election, the ODM also penetrated the Bukusu stronghold of FORD-K capturing two parliamentary seats and a moderate percentage of the presidential vote.

A number of factors explain the Luhya voting pattern in the 2007 presidential election. First, there was no Luhya presidential candidate, and therefore, their choice was guided by which party or coalition they perceived would take care of their interests, the ODM-K was not an option as it did not have a national outreach and Julia Ojiambo, their perceived point person, was a weakling politically as evident in her performance at the parliamentary level, where she managed to secure only 2 per cent of the vote. As for the PNU, Mwai Kibaki had Moody Awori as the Vice-President but that was a carryover from the MoU of 2002. Unlike Raila who had made it clear that he would make Mudavadi his Vice-President if he won, Kibaki was not categorical on the same. Furthermore, given events of the post 2002 General Election in which Kijana Wamalwa was made Vice-President without portfolio until Luhya MPs complained, most Luhyas it appeared did not trust Kibaki. In any case, as part of political machinations to rubbish the $2002 \mathrm{MoU}$, he had deftly appointed Moody Awori, a Luhya but from the LDP wing, to replace Wamalwa, a move that did not appease the FORD-K who felt that a Luhya nominee to the post should have come from the FORD-K ranks. There had also been unconfirmed reports that Kibaki under the NAK banner that preceded the NARC had promised Wamalwa that he would be a one-term president after which he would step down and back Wamalwa. The FORD-K tried to throw this argument albeit reluctantly to no avail.

Second, sub-tribe rivalry also played a role though with diminishing force as Bukusuland remained more entrenched towards the PNU through FORD-K and NFK while the other sub-tribes leaned more heavily towards the ODM.

The third factor was that having no presidential candidate made it a vote hunting ground and it was not surprising that all the three main presidential candidates had "running mates" from the community given that it is the second largest ethnic community.

\section{The 2013 General Election: A Luhya "Prodigal Son" Ends up in an Anti-Climax}

Since the return to multiparty politics, the 2013 presidential elections presented the Luhya community with their best shot at the presidency. As already noted, Wamalwa Kijana ran on a FORD-K ticket in 1997 and came a

Table 6. 2007 Presidential election results by province.

\begin{tabular}{|c|c|c|c|c|c|c|}
\hline Province & Kibaki & $\%$ & Odinga & $\%$ & Kalonzo & $\%$ \\
\hline Nairobi & 313,478 & 47.7 & 288,922 & 44 & 52,974 & 8.1 \\
\hline Coast & 197,354 & 33.1 & 353,773 & 59.4 & 38,881 & 6.5 \\
\hline North Eastern & 97,263 & 50.3 & 91,440 & 47.2 & 4498 & 2.3 \\
\hline Eastern & 835,481 & 50.4 & 83,575 & 5 & 726,782 & 43.8 \\
\hline Central & $1,741,086$ & 97 & 34,046 & 1.9 & 11,702 & 0.7 \\
\hline Rift Valley & 818,445 & 33.5 & $1,580,880$ & 64.6 & 33,863 & 1.4 \\
\hline Western & 312,300 & 32.2 & 639,246 & 65.9 & 6729 & 0.7 \\
\hline Nyanza & 262,627 & 16.9 & $1,280,978$ & 82.4 & 4476 & 0.3 \\
\hline Total & $4,578,034$ & 46.4 & $4,352,860$ & 44.1 & 879,899 & 8.9 \\
\hline
\end{tabular}

Source: Constructed from defunct Electoral Commission of Kenya, ECK, results. 
distant fourth but his candidature for all intents and purposes was meant to market him for future elections and consolidate the gains that the FORD-K had made as a political party. Mudavadi's candidature in 2013 was thus considered to be the best shot since the return to multiparty politics due to a number of factors. First, for the first time it appeared that a Luhya candidate had state backing. Although the incumbent Mwai Kibaki never came out openly to endorse him, there were significant events with political undertones that suggested that he was being groomed. These included Mudavadi's running on the UDF ticket-a party that was rumoured to have been formed by a close confidant of the president working in his office; riding on a state chopper to a national function on a public holiday; inviting the president to speak on a public holiday at a time that the Vice-President and the Prime Minister were out of the country; and, representing the President in a function when the Vice-President was in the country. All these events occurred after Mudavadi declared that he would be in the race for the presidency in mid-2012.

Second, the perceived preferred "state" candidate, Uhuru Kenyatta, was facing crimes against humanity charges and this posed two main challenges, i.e., his ability to competently compete if the date of the trials preceded the election date and the perceived potential for Kikuyu phobia given that Kibaki a Kikuyu was just finishing his five-year second-term. Mudavadi, therefore, was perceived to be a pliant candidate that could be used to checkmate Raila.

Third, Mudavadi's candidature in the initial stages appeared to be neutralising sub-tribe rivalry with some household names from the Bukusu sub-tribe such as the incoming Secretary General of UNCTAD, Mukhisa Kituyi, in his think tank.

Fourth, with state backing it was assumed he would have the financial muscle to carry out campaigns across the width and breadth of the country.

It was against this background that when Mudavadi launched his bid on $2^{\text {nd }}$ May 2012, the launch attracted MPs not just from the Luhya community across the various political parties with representation in the region (ODM, FORD-K and NFK) but it also appeared to cut across the politico-ethnic divide with most of the major political parties in the country represented in the event. ${ }^{3}$

With such a conglomeration of parties, Mudavadi's strategists and supporters were of the view that it was just a matter of time before the Luhya community rallied behind him in total. But before that could happen, Mudavadi had two major hurdles to overcome in his own backyard. First, he had to convince the other Luhyas who also had announced their interest in the presidency, namely, Eugene Wamalwa, Moses Wetang'ula and Cyrus Jirongo to drop their bids and back his. Second, he had to convince the remaining Luhya MPs that were reluctant to follow him to the UDF from the ODM. Both attempts collapsed as none of the aforementioned leaders was willing to step down in favour of Mudavadi and even the intervention of the Central Organisation of Trade Unions boss, Francis Atwoli, to spearhead Luhya unity talks came to nought. Likewise, he was unable to rope in the recalcitrant Luhya ODM MPs. In the long run, the Luhya leaders went separate ways with Mudavadi and Wamalwa teaming up under the Amani Coalition and Wetang'ula and Jirongo joining the CORD.

Mudavadi's initial forays into Central Kenya also elicited a lot of interest before Kenyatta launched his party — The National Alliance (TNA) — on 20 May 2012. The entry of Kenyatta into the race appeared to bust the bubble that the Mudavadi launch had inflated. His campaigns into Central Kenya subsequently failed to attract the crowds that it initially generated while his attempt to register a foothold in the Rift Valley, Coast and Nairobi did not manage to take-off.

As the Luhya leaders were busy attempting to identify a single leader to run for the presidency, other communities were also building alliances that would enable them to get into power. Uhuru and Ruto formed a political coalition, on 2 December 2012, between Uhuru's TNA and Ruto's United Republican Party (URP) that brought together the Kikuyu and the Kalenjin under one umbrella — the Jubilee Coalition. On the other hand, Odinga's ODM teamed up with Kalonzo's WDM and Moses Wetangula's FORD-Kenya, on $3^{\text {rd }}$ December 2012, to form

\footnotetext{
${ }^{3}$ The function was hosted by the UDF allied MPs Abdikadir Mohamed, George Nyamwea, Jeremiah Kioni, Maison Leshomo, Nderitu Muriithi, Njoroge Baiya, Katoo ole Metito, and Charles Ganya. These MPs were associated with Kenyatta and to many it sent the political message that Mudavadi's bid enjoyed the support of Kenyatta. Other non-UDF MPs present and are associated with Kenyatta and William Ruto included William Cheptumo, David Koech, Nelson Gaichuhie and Kareke Mbiuki. Kalonzo Musyoka’s Wiper Democratic Movement (WDM) was represented by Charles Kilonzo, Mahamud Sirat and Victor Munyaka. Cabinet minister Soita Shitanda, who is the New Ford-K party leader, as well as his party colleague Boni Khalwale and Ford-K Bifwoli Wakoli were also present. Others at the occasion were KANU Secretary General Nick Salat, former minister Mukhisa Kiyuti and former Vihiga MP Andrew Ligale. Coast MPs Kazungu Kambi, Fahim Twaha and Abu Chiaba and Najib Balala also attended the launch. ODM MPs George Khaniri, Yusuf Chanzu, Chris Okemo and Justus Kizito.
} 
the Coalition for Reforms and Democracy (CORD). ${ }^{4}$

The coming together of Odinga, Kalonzo and Wetangula had not been anticipated by the Jubilee Coalition and created panic in both the Jubilee Colaition and Mudavadi's handlers. This prompted the Jubilee to rope in Mudavadi in an agreement that was sealed late at night on the same day. In a private agreement between Kenyatta and Mudavadi, Kenyatta was reported to have agreed to step down for Mudavadi to fly the Jubilee flag. However, about 40 MPs associated with the TNA outrightly rejected the agreement and threatened to decamp from the alliance if Uhuru stepped down, on the grounds that the last minute entry of the UDF into the alliance was a scheme by State House operatives to compel Kenyatta to step down in favour of Mudavadi. The party delegates would later on vote to reject the agreement. The deal between Kenyatta and Mudavadi collapsed on $21^{\text {st }}$ December 2012 upon the signing of an Agreement on Consensual and Amicable Termination of the Addendum dated $4^{\text {th }}$ December 2012.

With the collapse of the anticipated crowning of Mudavadi as the Jubilee candidate, on $4^{\text {th }}$ January 2013, Mudavadi was endorsed as the presidential candidate of the UDF in an event that also rolled out the Amani Coalition bringing together the UDF, KANU (which had already signed a pact with UDF on 4 December 2012), and Eugene Wamalwa's NFK. ${ }^{5}$ Wamalwa did not contest for any elective seat but instead campaigned for Mudavadi's presidential bid. ${ }^{6}$ The strategy here was meant to enable Mudavadi penetrate the Bukusu sub-tribe of the Luhya. $^{7}$

After being outmanoeuvred by Kenyatta, it was evident that the bubble around the Mudavadi candidature had fizzled away. However, through Amani, Mudavadi's handlers and the anti-Raila brigade thought his candidature could still be useful by locking out CORD from Luhyaland. With Musalia Mudavadi in the race, there was anticipation among Luhya unity enthusiasts that this time round one of their own would be able to deliver the Luhya vote, and probably use it as a bargaining chip in case the presidential election went for a run-off. The yardstick appeared to have been borrowed from the 2002 and 2007 election results in which candidates with no chance of making it still galvanized their community respectively, i.e., Simeon Nyachae with the Kisii and Kalonzo Musyoka with the Kamba in the respective years (Table 7).

Table 7. 2013 Presidential election results by province.

\begin{tabular}{|c|c|c|c|c|c|c|}
\hline Region & Kenyatta & $\%$ & Odinga & $\%$ & Mudavadi & $\%$ \\
\hline Central & $1,895,075$ & 93.92 & 84,010 & 4.16 & 4284 & 0.21 \\
\hline Coast & 158,083 & 19.34 & 612,057 & 74.9 & 10,564 & 1.29 \\
\hline Eastern & 848,234 & 46.96 & 881,455 & 48.8 & 12,802 & 0.71 \\
\hline Nairobi & 659,490 & 46.75 & 691,156 & 49 & 22,061 & 1.56 \\
\hline North Eastern & 175,032 & 59.58 & 98,802 & 33.63 & 834 & 0.28 \\
\hline Nyanza & 181,961 & 10.47 & $1,508,776$ & 86.83 & 15,257 & 0.88 \\
\hline Rift Valley & $2,188,422$ & 72.22 & 707,541 & 23.35 & 64,295 & 2.12 \\
\hline Western & 66,185 & 5.45 & 755,525 & 62.22 & 353,864 & 29.14 \\
\hline Diaspora & 951 & 40.85 & 1224 & 52.58 & 20 & 0.86 \\
\hline Total & $6,173,433$ & 50.07 & $5,340,546$ & 43.31 & 483,981 & 3.93 \\
\hline
\end{tabular}

Source: Constructed from Independent Electoral Commission of Kenya results.

${ }^{4}$ Ten other parties - the People’s Democratic Party (PDP) led by former South Mugirango MP Omingo Magara, the Kenya Social Congress (KSC), the Mkenya Solidarity associated with former Mungiki leader Maina Njenga, The Independent Party (TIP) associated with Kalembe Ndile, Chama cha Uzalendo associated with Wanyiva Ndeti, KADDU Asili, the United Democratic Movement (UDM), Agano Party and Muungano Party associated with Kivutha Kibwana-also signed up to be members.

${ }^{5}$ The other coalition which had managed to bring at least two key Luhya leaders together was the once between the Wamalwa's NFK, Jirongo's FPK and Biwott's National Vision Party (NVP). The other parties' party to this coalition were the Kenya African Democratic Union-Asili and Shirikisho Party of Kenya (SPK). This coalition would later be dissolved on 29 December 2012, when the FPK, the NVP and the SPK announced the dissolution as a result of Wamalwa's flirtation with other parties outside the coalition without the consent of other coalition partners. The FPK has since joined the CORD while the NFK has joined the Amani coalition.

${ }^{6}$ According to the deal, Wamalwa would be given first priority when it came to nominations to Parliament, supported to be Speaker of the National Assembly, granted first priority in the nomination of Cabinet Secretaries or either Majority or minority leader depending on the strength of MPs of the Alliance.

${ }^{7}$ Apart from Wamalwa, Mudavadi was also depending on Mukhisa Kituyi, Soita Shitanda, George Khaniri, Manyala Keya, Musikari Kombo Kizito Mugali, Bonny Khalwale, Yusuf Chanzu, Ben Washiali, Alfred Sambu to market his bid in the region. In Rift Valley Province, Mudavadi banked on KANU to market his presidential bid. 
The results however proved otherwise. Not only did Mudavadi register a paltry 3.93 of the national vote but he also failed to galvanize the Luhya vote. Odinga beat him in Western province by garnering 62.22 per cent against his 29.14 per cent. Mudavadi actually became the first serious candidate from the big five to fail to win the vote from his community since the return to multiparty politics in 1992. Table 8 shows that even in his own county—Vihiga — where he got (49.19 per cent) he barely defeated Odinga (46.44 per cent) by a mere 2.75 percentage points.

The results of the other key five elective posts further proved that the fact that a Luhya was running for the presidential seat was not a guarantee that those who were running under his coalition would be elected. This is different from the situation obtaining in other regions. Apart from the Luo and the Kikuyu overwhelmingly voting for their presidential candidates, their respective candidates for the other elective posts managed to clinch the most if not all of the seats in Luoland and Central regions respectively. The inability of the Amani Coalition to deafeat CORD, especially the ODM wing which might have been considered as a non-indigenous party in the region can be attributed to the fact that unlike in the Rift Valley where Odinga in 2013 would have had to go through Ruto to secure the votes in that region, in the Western Region Odinga/ODM/CORD had a direct presence and could engage directly with the voters. On top of that they had formidable political beacons from the community (Table 9).

Table 8. 2013 presidential election results western province counties.

\begin{tabular}{cccccccc}
\hline County & Kenyatta & \% & Odinga & \% & Mudavadi & \% \\
\hline Busia & 8186 & 3.71 & 189,161 & 85.62 & 18,608 & 8.42 \\
Kakamega & 12,469 & 2.63 & 303,120 & 63.84 & 144,962 & 30.53 \\
Bungoma & 42,988 & 12.25 & 185,419 & 52.83 & 107,868 & 30.73 \\
Vihiga & 2542 & 1.52 & 77,825 & 46.44 & 82,426 & 49.19 \\
Trans-Nzoia & 74,466 & 37.24 & 92,035 & 46.03 & 24,762 & 12.38 \\
\hline
\end{tabular}

Source: Constructed from Independent Electoral Commission of Kenya results.

Table 9. Party seats in Western Kenya in the 2013 election.

\begin{tabular}{|c|c|c|c|c|c|}
\hline Coalition & Party & Governor (\%) & Senator (\%) & Women Rep. (\%) & MP (\%) \\
\hline \multirow{4}{*}{ CORD } & ODM & 40 & 20 & 60 & 31.6 \\
\hline & FORD-K & 20 & 40 & - & 15.8 \\
\hline & FPK & - & - & - & 5.3 \\
\hline & Total & 60 & 60 & 60 & 52.6 \\
\hline \multirow{3}{*}{ Amani } & NFK & 20 & - & 40 & 10.5 \\
\hline & UDF & - & 40 & - & 21.1 \\
\hline & Total & 20 & 40 & 40 & 31.6 \\
\hline \multirow[t]{2}{*}{ Jubilee } & URP & - & - & - & 7.9 \\
\hline & PPK & 20 & - & - & - \\
\hline \multirow{3}{*}{ Unaffiliated } & MDP & - & - & - & 2.6 \\
\hline & Ind. & - & - & - & 5.3 \\
\hline & Total & 20 & - & - & 15.8 \\
\hline
\end{tabular}

Source: Constructed from Independent Electoral Commission of Kenya results. 


\section{Factors That Impeded Mudavadi's Quest to Galvanize the Luhya Vote}

My analysis has shown that since the return to multiparty politics, it is only the Luhya tribe out of the big five that has never overwhelmingly rallied behind one of their own in a presidential election. I demonstrated that when there was a modicum of a block vote by the Luhya community in 2002, it was for a Kikuyu candidate, Mwai Kibaki and was more likely out of a national psyche as epitomised in the NARC coalition to bring an end to Moi's dictatorial regime and his "project” Uhuru rather than a bloc vote driven by ethnic identity consciousness.

I have also demonstrated how the other big four communities, namely, the Kikuyu, the Luo, the Kalenjin and the Kamba, have in different electoral presidential races rallied behind one of their own especially when the candidate is perceived to have a national stature. These include Moi, Matiba, Kibaki and Odinga in 1992; Moi, Kibaki and Raila in 1997; Kibaki, Uhuru and Nyachae in 2002; and, Kibaki, Raila and Kalonzo in 2007. In fact in the 2013 General Election, the running mates of Uhuru and Raila, in this case William Ruto and Kalonzo Musyoka respectively, rallied their communities behind their presidential candidates. This begs the question as to why Mudavadi, who was an outdoing Deputy Prime Minister (DPM) under the Coalition Government, was unable to rally his community in a country where ethnic identity remains the strongest mobilisation tool especially for the big five.

The first factor is that Mudavadi, from the word go, was perceived to be a "project" of the state. Mudavadi had been a loyal deputy of Raila Odinga in the ODM - a fact that contributed to William Ruto decamping form the ODM when Raila opted to nominate Mudavadi to the DPM's position and also stuck with Mudavadi when Ruto pitched for the Deputy Party Leader position by getting the ODM to create a second post to ensure that both Ruto and Mudavadi were accommodated. Thus, when Mudavadi abruptly declared his bid for the presidency compelling the ODM to change its constitution to accommodate his candidature in the party primaries, it appeared that he was pushing for the quest as an excuse to leave the party. In fact, as the ODM started the process of amending its constitution to accommodate Mudavadi's demands, it was clear that he did not have the mantle to beat Odinga in the ODM primaries.

In the end, he still decamped with a number of Luhya MPs but a majority of the Luhya MPs stuck with the ODM. Mudavadi had earlier been captured in a television clip alluding to pressure on him to break ranks with Odinga. The subsequent state patronage we alluded to earlier and the last minute deal for Uhuru to step down for him all fuelled the "project” mantra and in the end Mudavadi was perceived not to be his own man even by his Luhya community. The fact that he reneged to join the CORD even after his own admission that he had been belittled by Uhuru on their private deal further hurt his stature within the Luhya community.

Second, unlike the other big four communities that had a dominant party which their community paid allegiance to, i.e., Kikuyu, the TNA, Luo, the ODM, Kalenjin, the URP, and Kamba the WDM, his party, the UDF, was not dominant amongst the Luhya as the results attested, with the ODM even more popular than the UDF among the Luhyas. Furthermore, the FORD-K and NFK also had a significant presence in Luhyaland, especially among the Bukusu sub-tribe. In any event, his alliance with Wamalwa's NFK only gave him a modicum of presence in Bukusuland as the FORD-K and the ODM under the CORD banner commanded a stronger presence in Bukusuland.

Third, since the 2002 General Election in Kenya, the electioneering process has always shaped into a two horse race. In 2002, although Nyachae's FORD-P was in the race, the contest was between the NARC and the KANU. In 2007, although Kalonzo's ODM-K was in the race, the contest was between Mwai Kibaki's the PNU and Raila Odinga's the ODM. And thus in 2013, after the Jubilee disowned Mudavadi in the short-lived marriage, the contest was between Uhuru's Jubilee Coalition and Raila's CORD. The lesson of 2002 when Nyachae rallied his Kisii community and still came a distant third and the lesson of Kalonzo rallying his Kamba community and still coming a distant third must have played in the Luhya psyche especially after the CORD went on the onslaught with the adage that "a vote for Mudavadi was a vote for Uhuru” since Mudavadi stood no chance of winning the race.

Fourth, Mudavadi's campaign strategy after being dumped by the Jubilee was inward looking and defeatist. Mudavadi's campaign spent the first five official campaign days as well as the last five official campaign days in Luhyaland. In fact Mudavadi's campaign veered off the official campaign schedule submitted to the Independent Electoral and Boundaries Commission (IEBC) in order to concentrate the last leg of its campaign in Luhyaland. This siege mentality of locking in the Luhya vote appears not to have resonated with the Luhyas as a 
campaign that had started with national pride was reduced to ethnic canvassing in anticipation of a run-off. In addition, the CORD had strong Luhya political beacons on the ground that slowed down the Amani brigade. These included Moses Wetangu'la, Ababu Namwamba, Amos Wako, Cyrus Jirongo, Wycliffe Oparanya, among others. Their presence augmented the Luhya psyche that they were just at "home" and well represented in the CORD just as they would be in Mudavadi's Amani and the difference was that the CORD had a realistic shot at the presidency while Amani did not.

Fifth, Mudavadi's Amani coalition fell short of the impetus that the CORD and the Jubilee had in the choice of running mates. The results clearly show the added valued that Kalonzo and Ruto brought to their respective coalitions (Figure 1). In the case of Mudavadi, once the CORD and Jubilee principals had bagged the big four, there was no other big tribe to add to the potential Luhya bloc vote. The end result was that Mudavadi settled on Jeremiah Kioni from the Kikuyu who already had a presidential candidate and who since the return to multiparty politics have never voted for an outsider. It was like throwing in the towel and most likely played on the Luhya psyche.

Sixth, Mudavadi was unable to overcome sub-tribe identity in the same manner that Moi and Ruto have done with the Kalenjin. The end result was that there were some no go areas for him such as Busia and until the entry of Wamalwa into his coalition, Bukusuland.

Seventh, Mudavadi's past political wavering and lack of a record in pushing for Luhya unity must have slowed his quest to carry the Luhya banner. When Kijana Wamalwa offered his candidature in 1997, he stuck with the KANU and delivered for the then ruling party. When the Luhyas joined the national coalition in NARC, he reneged and rejoined the KANU. These two instances when he chose to dalliance with forces opposed to what might have been perceived as the community's course in those two instances must have struck a raw nerve amongst the Luhyas that he was not the right person to peg a community's destiny on.

\section{Conclusion}

A combination of factors has been used to explain why the Luhya have been unable to register a serious presidential bid in the five General Elections held since 1992. The most critical factor has been the inability of the candidates from the region to draw traction from outside the Luhya stronghold of Western Province, which may be as a result of a perception that none of the candidates who have contested for the presidency has a serious chance of winning the presidency. Tied to this would be the nature of the sub-ethnic groups amongst the Luhya. There are a total of about 18 sub-ethnic groups among the Luhya with the Bukusu (Bungoma) and the Maragoli (Vihiga) constituting about 70 per cent of the Luhya population. ${ }^{8}$ The Bukusu are found mostly in Bungoma and the

Kioni

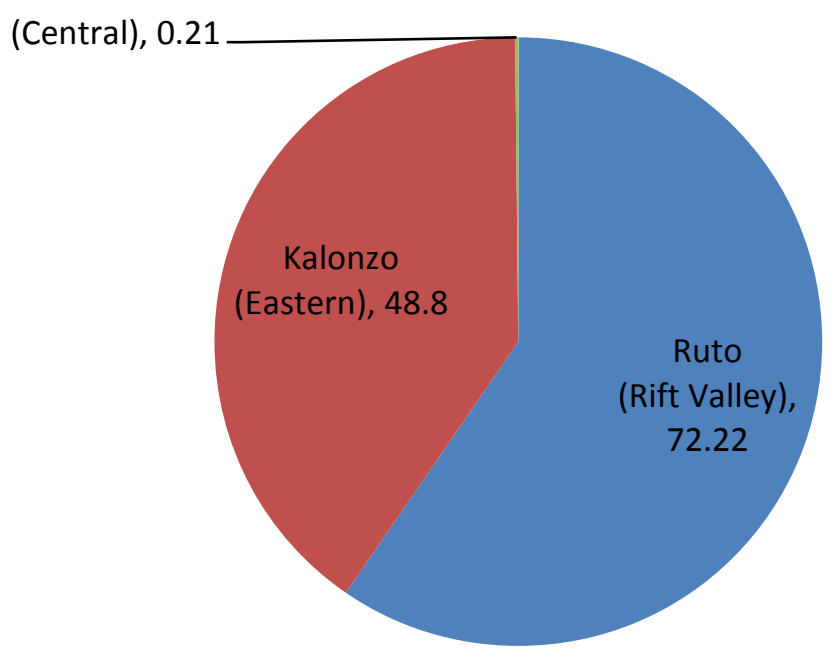

Figure 1. Running mates contribution in the 2013 presidential election.

\footnotetext{
${ }^{8}$ The other sub-ethnic groups are the Idakho, Isukha, Tsotso and Kabras (Kakamega), Khayo, Marachi, Nyala and Samia (Busia) Kisa, Marama and Wanga (Butere/Mumias), Nyole and Tiriki (Vihiga).
} 
greater Trans-Nzoia region, which although in the Rift Valley, votes akin to their counterparts in Western Province. Historically, these two sub-tribes have politically followed different paths. The Luhya's also lack a dominant party akin to the other four big tribes. But more importantly, no leader has arisen among the Luhya with the pedigree and charisma that cuts across the sub-tribes and who convincingly coins a convincing narrative to chart a Luhya "course" as a block.

\section{References}

[1] Oloo, A. (2010) Party Mobilization and Membership: Old and New Identities in Kenyan Politics. In: Kanyinga, K. and Okello, D., Eds., Tensions and Reversals in Democratic Transitions: The Kenya 2007 General Elections, SID/IDS, Nairobi, 31-60.

[2] Horowitz, D. (1985) Ethnic Groups in Conflict. California University Press, Berkeley.

[3] Throup, D. and Hornsby, C. (1998) Multi-Party Politics in Kenya. East African Educational Publishers, Nairobi.

[4] Oyugi, W. (1997) Ethnicity in the Electoral Process: The 1992 General Elections in Kenya. African Journal of Political Science, 2, No. 1.

[5] Tostensen, A., Andreassen, A. and Tronvoll, K. (1998) Kenya’s Hobbled Democracy Revisited: The 1997 General Elections in Retrospect and Prospect. Norwegian Institute of Human Rights, University of Oslo.

[6] Oyugi, W.O. (2006) Coalition Politics and Government in Africa since Independence. Journal of Contemporary African Studies, 24, No. 1. http://dx.doi.org/10.1080/02589000500513739

[7] Wanyande, P. (2006) Electoral Politics and Election Outcomes in Kenya. Africa Development, XXXI, No. 3. 